\title{
Solubility Prediction of Solutes in Non-Aqueous Binary Solvent Mixtures
}

\author{
Abolghasem Jouyban, ${ }^{*, a}$ Maryam Khoubnasabjafari, ${ }^{b}$ Somaieh Soltani, ${ }^{c}$ Shahla Soltanpour, ${ }^{d}$ \\ Elnaz Tamizi ${ }^{i}$ and William E. Acree Jr.f
}

${ }^{a}$ Faculty of Pharmacy and Drug Applied Research Center, Tabriz University of Medical Sciences, 51664, Iran

${ }^{b}$ Kimia Research Institute, P.O. Box 51665-171, Iran

${ }^{c}$ Research Center for Pharmaceutical Nanotechnology, Tabriz University of Medical Sciences, 51664, Iran

${ }^{d}$ Biotechnology Research Centre, Tabriz University of Medical Sciences, 51664, Iran

eStudent Research Center, Tabriz University of Medical Sciences, 51664, Iran

${ }^{f}$ Department of Chemistry, University of North Texas, Denton, TX 76203-5070, USA

Foi investigada a possibilidade de substituir os parâmetros de Abraham calculados teoricamente pelos parâmetros experimentais, na previsão da solubilidade de solutos não-aquoso em misturas de solventes binários, utilizando-se o modelo de Jouyban-Acree. As solubilidades de 90 conjuntos de dados, coletados a partir da literatura, foram preditas utilizando-se estes parâmetros, os coeficientes de solventes e também as solubilidades de sistemas mono-solventes. A precisão das solubilidades previstas foi avaliada calculando-se a média percentual do desvio (MPD) e também dos desvios percentuais (IPDs) individuais. O MPD global para a análise utilizando os parâmetros de Abraham, experimentais e teóricos, foram os mesmos e $<14 \%$. Uma boa distribuição (IPD) foi obtida por estas análises numéricas. Os conjuntos de dados investigados neste trabalho foram coletados a várias temperaturas e os resultados confirmaram a possibilidade de previsão da solubilidade em solventes binários a diferentes temperaturas. Explorou-se a possibilidade de cálculos ab initio nesta previsão utilizando as solubilidades calculadas em sistemas mono-solventes. No entanto, a diferença entre os valores previstos e observados, para os coeficientes dos solventes, aumentou para aproximadamente $60 \%$ e $200 \%$ quando usou-se gás e água, respectivamente. Estes, são valores muito grandes para várias aplicações de previsão.

The possibility of replacing theoretically computed Abraham parameters with the experimental Abraham parameters in solubility prediction of solutes in non-aqueous binary solvent mixtures using the Jouyban-Acree model was investigated. The solubilities of 90 data sets collected from the literature were predicted using their Abraham parameters, the solvent coefficients and also the solubilities in mono-solvent systems. The accuracy of the predicted solubilities was evaluated by calculating the mean percentage deviation $(M P D)$ and also individual percentage deviations $(I P D \mathrm{~s})$. The overall $M P D$ for the analysis using experimental and computed Abraham parameters were the same and was $<14 \%$. A favoured $I P D$ distribution was obtained for these numerical analyses. The data sets investigated in this work were collected at various temperatures and the results confirmed the possibility of solubility prediction in binary solvents at various temperatures. We did explore the possibility of ab initio solubility prediction of solutes in binary mixtures using the calculated solubilities in mono-solvent systems, however, the difference between the predicted and observed values increased to $c a$. $60 \%$ for gas-to-solvent coefficients and $c a$. $200 \%$ for waterto-solvent coefficients, which is too large for many predictive applications.

Keywords: solubility, prediction, non-aqueous mixed solvents, Abraham model, JouybanAcree model

\section{Introduction}

Solubility of a solute is affected by solvent's and

*e-mail: ajouyban@hotmail.com solute's chemical structures and could be mathematically represented using meaningful parameters like Abraham solvation parameters. The Abraham solvation parameter models provided numerical methods for prediction of solutes' solubility in a wide variety of neat organic solvents. ${ }^{1-6}$ The 
Abraham models employ five parameters for each solute and six solvent coefficients that were computed for a number of common solvents. ${ }^{3-4}$ The basic models proposed for process within condensed phases is:

$\log \left(\frac{C_{S}}{C_{W}}\right)=c+e \cdot E+s \cdot S+a \cdot A+b \cdot B+v \cdot V$

and for process involving gas-to-condensed phase transfer is:

$\log \left(\frac{C_{S}}{C_{G}}\right)=c+e \cdot E+s \cdot S+a \cdot A+b \cdot B+l \cdot L$

where $C_{S}$ and $C_{W}$ are the solute solubility in the organic solvent and water (in mole per liter), respectively, $C_{G}$ is the gas phase concentration of the solute, $E$ is the excess molar refraction, $S$ is dipolarity/polarizability of solute, $A$ denotes the solute's hydrogen-bond acidity, $B$ stands for the solute's hydrogen-bond basicity, $V$ is the McGowan volume of the solute, and $L$ is the logarithm of the solute gas-hexadecane partition coefficient at $298.15 \mathrm{~K}$. In equations (1) and (2) the coefficients $c, e, s, a, b, v$ and $l$ are the model constants (i.e. solvent's coefficients), which depend upon the solvent system under consideration. Numerical values of the model constants have been reported in the literature ${ }^{3-4}$ for several water-to-organic solvent and gas-to-organic solvent systems.

Solvent mixing or cosolvency is the most common method to alter the solubility of a solute. There is an infinite number of solvent compositions for a given binary solvent, and for some compounds, both linear and nonlinear solubility behavior have been reported in mixed solvent systems. The most accurate model to represent the solubility data in mixed solvent systems is the JouybanAcree model..$^{7-9}$ Its general form is:

$\ln X_{m}=f_{1} \ln X_{1}+f_{2} \ln X_{2}+f_{1} f_{2} \sum_{j=0}^{2} B_{j}\left(f_{1}-f_{2}\right)^{j}$

where $\mathrm{X}$ is the mole fraction solubility of the solute, $\mathrm{f}$ denotes the mole fraction of the solvents 1 and 2 in the solvent mixture, subscripts $\mathrm{m}, 1$ and 2 are the mixed solvent and solvents 1 and 2, respectively, $B_{j}$ is the model constant which represent various solute-solute, solvent-solvent and solute-solvent interactions. In a previous study, ${ }^{10}$ QSPR models were proposed to calculate the numerical values of the $B_{j}$ terms using the Abraham coefficients for 22 solvents and solute descriptors for 5 solutes.

The QSPR models proposed in an earlier work using water-to-solvent coefficients were:

$$
\begin{aligned}
B_{0}= & 0.028+2.123\left(c_{1}-c_{2}\right)^{2}-0.160 E\left(e_{1}-e_{2}\right)^{2}+0.282 S\left(s_{1}-s_{2}\right)^{2} \\
& +1.713 B\left(b_{1}-b_{2}\right)^{2}+2.006 V\left(v_{1}-v_{2}\right)^{2}
\end{aligned}
$$

$$
\begin{aligned}
B_{1}= & 0.033+0.670\left(c_{1}-c_{2}\right)^{2}-0.477 E\left(e_{1}-e_{2}\right)^{2}+0.051 S\left(s_{1}-s_{2}\right)^{2} \\
& +0.476 B\left(b_{1}-b_{2}\right)^{2}-0.234 V\left(v_{1}-v_{2}\right)^{2} \\
B_{2}= & 0.022+2.024\left(c_{1}-c_{2}\right)^{2}-0.204 E\left(e_{1}-e_{2}\right)^{2}+0.034 S\left(s_{1}-s_{2}\right)^{\prime} \\
& +0.243 B\left(b_{1}-b_{2}\right)^{2}+0.848 V\left(v_{1}-v_{2}\right)^{2}
\end{aligned}
$$

and the QSPR models using gas-to-solvent coefficients were:

$$
\begin{aligned}
B_{0}= & 0.062+0.118\left(c_{1}-c_{2}\right)^{2}-0.332 E\left(e_{1}-e_{2}\right)^{2}+0.410 S\left(s_{1}-s_{2}\right) \\
& +2.399 B\left(b_{1}-b_{2}\right)^{2}+15.715 L\left(l_{1}-l_{2}\right)^{2} \\
B_{1}=0.103-1.864\left(c_{1}-c_{2}\right)^{2}-1.590 E\left(e_{1}-e_{2}\right)^{2}+0.119 S\left(s_{1}-s_{2}\right)^{c} & \\
& +1.010 B\left(b_{1}-b_{2}\right)^{2}-9.493 L\left(l_{1}-l_{2}\right)^{2} \\
B_{2}=- & 0.008+1.075\left(c_{1}-c_{2}\right)^{2}+0.053 E\left(e_{1}-e_{2}\right)^{2}+0.084 S\left(s_{1}-s_{2}\right)^{2} \\
& +0.414 B\left(b_{1}-b_{2}\right)^{2}+7.727 L\left(l_{1}-l_{2}\right)^{2}
\end{aligned}
$$

The applicability of the proposed method was checked using 194 solubility data sets of five different solutes in various non-aqueous binary solvents. In this work, the possibility of replacing experimentally obtained Abraham parameters with the computed parameters is examined. The prediction capability of the previously developed QSPR models is checked using 90 solubility data sets ${ }^{11-24}$ of solutes which were not used in training process of the QSPR models. The applicability of the proposed method is also shown for predicting solubility at various temperatures. The main limitation of the Abraham model is that solute solvational parameters are known for only 4,000 organic compounds. In a recently released software ${ }^{25}$, this limitation is overcome and one is able to compute $E, S, A, B, V$ and $L$ parameters.

\section{Computational Methods and Experimental Data}

The solubilities of the solutes in binary solvent mixtures were collected from the literature. ${ }^{11-24}$ Table S1 listed details of the experimental solubility data. The numerical values of the solvents' coefficients were listed in Table S2. In addition to the experimental database of solute's parameters, commercial software is also available to compute the parameters. ${ }^{25}$ Table S3 lists the experimental and computed values of solute's parameters. Since the numerical values of $A$ term for the solutes studied in the previous paper ${ }^{10}$ were equal to zero, the corresponding terms have been omitted from the QSPR models.

The $B_{j}$ constants of the Jouyban-Acree model were computed using equations (4)-(6) and (7)-(9), and these model constants were then used to predict the solubilities 
Table 1. Details of various numerical analyses carried out using experimental and computed Abraham parameters

\begin{tabular}{lll}
\hline Method No. & $B_{j}$ terms computed by & Solubility in mono-solvents \\
\hline I & Water-to-solvent coefficients (equations (4)-(6)) & Experimental data \\
II & Gas-to-solvent coefficients (equations (7)-(9)) & Experimental data \\
III & Water-to-solvent coefficients (equations (4)-(6)) & Computed by equation (1) \\
IV & Gas-to-solvent coefficients (equations (7)-(9)) & Computed by equation (2) \\
\hline
\end{tabular}

of solutes in binary solvents. The predictions still required numerical values of the solute solubility in each pure solvent, i.e. $X_{1}$ and $X_{2}$. In order to provide a predictive model (without any experimentally determined data), $C_{S}$ values of the solutes in the neat solvents under consideration were computed using Abraham models (using experimental values of $C_{W}$ or $C_{G}$ ). The calculated molar solubilities, $C_{S}$, were converted to the mole fraction solubilities using density of the pure organic solvent. The calculated $X_{1}$ and $X_{2}$ values were then substituted into equation (3), along with the $B_{j}$ values from equations (4)-(6) (or equations (7)-(9)) to predict the solubility in binary solvents by the JouybanAcree model. The density of pure organic solvents has been used to convert the molar solubility to mole fraction solubility and the effect of solute on density of the solution has been ignored. Table 1 summarizes the various numerical methods discussed in this work.

The predicitve ability of each computational method was assessed in terms of the mean percentage deviation $(M P D)$ of observed $\left(\left(X_{m}\right)_{o b s}\right)$ and calculated $\left(\left(X_{m}\right)_{c a l}\right)$ solubilities, defined by equation (10):

$M P D=\frac{100}{N} \sum \frac{\left|\left(X_{m}\right)_{c a l .}-\left(X_{m}\right)_{o b s .}\right|}{\left(X_{m}\right)_{o b s .}}$

where $N$ is the number of data points. In addition, we also calculated the individual percentage deviation $(I P D)$ :

$I P D=100\left\{\frac{\left(X_{m}\right)_{c a l .}-\left(X_{m}\right)_{o b s .} \mid}{\left(X_{m}\right)_{o b s .}}\right\}$

for each solubility data point.

\section{Results and Discussion}

Validation of the previously derived coefficients for solubility predictions using computed Abraham solute descriptors

The solubilities of the solutes in 194 different binary solvent mixtures (for details see Table 1 of a previous paper ${ }^{10}$ ) were predicted using the Jouyban-Acree model and calculated $B_{j}$ values based on equations (4)-(6) and
(7)-(9). Both experimental and computed Abraham solute descriptors were used in the $B_{j}$ calculationss. Table 2 gives the overall $M P D( \pm \mathrm{SD})$ values for the four predictive methods employed. There are no significant differences between MPDs for methods I and II that used experimental or computed Abraham parameters and experimental values of $X_{1}$ and $X_{2}$ ( $t$-test, $\left.\mathrm{p}>0.05\right)$. This observation is important in that it is possible to use computed solute descriptors instead of experimentally based values for predicting $B_{j}$ constants of the Jouyban-Acree model. However, significant differences are observed using predicted $X_{1}$ and $X_{2}$ by equations (1) and (2) for the same set of data and the coefficients $(p<0.0005)$, revealing that the computed Abraham parameters using PharmaAlgorithm software produced less accurate solubility predictions in monosolvent systems in comparison with the experimental Abraham parameters. To confirm this hypothesis, readers could refer to the predicted solubilities using equations (1) and (2) employing experimental Abraham parameters. As examples, the IPDs of the predicted solubilities of anthracene using equation (1) in various solvents were listed in Table S4 where the differences between predicted solubilities using experimental and computed Abraham parameters were statistically significant (paired t-test, $\mathrm{p}<0.001$ or $\mathrm{p}<0.0005$, for details see footnote of

Table 2. Overall MPD $( \pm \mathrm{SD})$ for solubility prediction of 194 sets from a previous work, ${ }^{10}$ and this work using experimental and computed Abraham solute parameters

\begin{tabular}{llll}
\hline $\begin{array}{l}\text { Numerical } \\
\text { method }\end{array}$ & $\begin{array}{l}\text { Experimental } \\
\text { parameters }\end{array}$ & $\begin{array}{l}\text { Computed } \\
\text { parameters }\end{array}$ & Significance \\
\hline \multicolumn{4}{c}{194 data set from a previous work } \\
\hline I & $4.6 \pm 3.9$ & $4.6 \pm 4.0$ & Not significant \\
II & $11.3 \pm 13.3$ & $10.5 \pm 13.0$ & Not significant \\
III & $33.0 \pm 20.6$ & $52.0 \pm 32.2$ & $\mathrm{p}<0.0005$ \\
IV & $23.9 \pm 21.5$ & $118 \pm 258.4$ & $\mathrm{p}<0.0005$ \\
\hline & & This work & \\
\hline I & $13.7 \pm 14.0$ & $13.6 \pm 13.8$ & Not significant \\
II & $12.7 \pm 13.9$ & $12.5 \pm 13.7$ & Not significant \\
III & $228.4 \pm 337.7$ & $168.8 \pm 325.4$ & Not significant \\
IV & $53.5 \pm 30.0$ & $62.7 \pm 43.6$ & $\mathrm{p}<0.016$ \\
\hline
\end{tabular}


Table S4). A possible reason for such deviations could be the non-ideally adjusted water-to-solvent coefficients of some solvents as it was reported slightly different $c, e, s$, $a, b$ and $v$ values for cyclohexane in an earlier report ${ }^{1}$ and a recent one ${ }^{5}$ in which the IPD of anthracene solubility in cyclohexane predicted by equation (1) using earlier ${ }^{1}$ and amended $^{5} c, e, s, a, b$ and $v$ values were 213.2 and $148.4 \%$, respectively. We have computed the IPD of anthracene in cyclohexane using amended ${ }^{5} c, e, s, a, b$ and $v$ values equal to $149.6 \%$. The second reason for very large deviations between theoretically derived and experimentally determined solubility values could be any error in the solute's parameter calculations. The third reason could be the temperature effects on $X_{1}$ and $X_{2}$ values which did not considered in the equations (1) and (2).

It is possible to improve our $a b$ initio prediction approach by developing better methods to predict the solubility in mono-solvent systems. It is difficult to guesstimate the error that one could reasonably expect from employing predictive methods to estimate the solubility in the neat organic solvents as the published methods have been tested on relatively few of the many possible solute-solvent combinations. Based on our review of the published comparisons, we do not think that it would be unreasonable to assign an expected error in the range of 0.1 to $0.3 \log$ units to solubilities predicted by group contribution and linear free energy correlations for many of the simpler systems.

\section{Predictions using water-to-solvent process and experimental solubility data in mono-solvents}

The predictive calculations discussed in the preceding section concerned solubility data used in generating equations (4)-(9). A more stringent test of any predictive solubility method is its ability to accurately predict solubilities of additional solute molecules, or solubilities of solutes dissolved in additional binary solvent mixtures. To better assess the applications and limitations of methods I-IV, we have compiled from the published literature experimental solubility data for 90 additional data sets (see Table S1). In the first set of calculations on the new data set, we computed the $B_{j}$ coefficients using equations (4)-(6) and experimentally-based Abraham solute descriptors. The calculated $B_{j}$ values were then combined with experimentally measured solubility data in the mono-solvents to predict the mole fraction solubility $\ln X_{m}$ values for the 90 additional data sets (numerical method I of Table 1) using equation (3). The prediction accuracy of the data was evaluated using MPD values for this analysis and reported in column 2 of Table S5. The minimum $(0.2 \%)$ and maximum $(61.6 \%)$ MPDs were observed for p-benzoquinone in 2, 2, 4-trimethylpentane + cyclohexane and benzophenone in carbon tetrachloride + dodecane mixtures both at $25^{\circ} \mathrm{C}$. The overall MPD $( \pm \mathrm{SD})$ was $13.7 \pm 14.0 \%$. A similar set of calculations were performed using computed Abraham parameters by PharmaAlgorithm software (see column 6 of Table S5). The minimum $(0.2 \%)$ and maximum $(61.8 \%)$ MPDs were observed for the same data sets and the overall $M P D$ $( \pm \mathrm{SD})$ was $13.6 \pm 13.8 \%$. There was no significant difference between 13.7 and $13.6 \%$ (paired $t$-test, $\mathrm{p}>0.05$ ). Figures 1 and 2 showed the relative frequencies of IPDs sorted in three subgroups, i.e. $\leq 4,4-30$ and $>30 \%$, for various numerical methods employing experimental and computed Abraham parameters. There was no significant difference between frequencies of IPDs of both parameters for numerical method I. Figure S1 depicted the overall $M P D$ s for various solutes and there was no difference between $M P D$ s calculated using experimental and computed Abraham parameters. These findings confirm the above results using 194 data sets from a previous work ${ }^{10}$ and reveal that it is possible to replace the experimentally determined Abraham parameters with the computationally obtained parameters for solubility prediction in mixed solvent system using method I.

The equations (4)-(6) were obtained employing the $B_{j}$ terms calculated using solubility data of solutes at 25 and $26{ }^{\circ} \mathrm{C}$, however, the equations were able to predict the solubility a wider temperature range $\left(20-50{ }^{\circ} \mathrm{C}\right)$ as is evident (as examples) from set numbers $1-7$ or $8-14$ of Table S1. This is an oversimplification on the constants of the Jouyban-Acree model where it has been assumed that

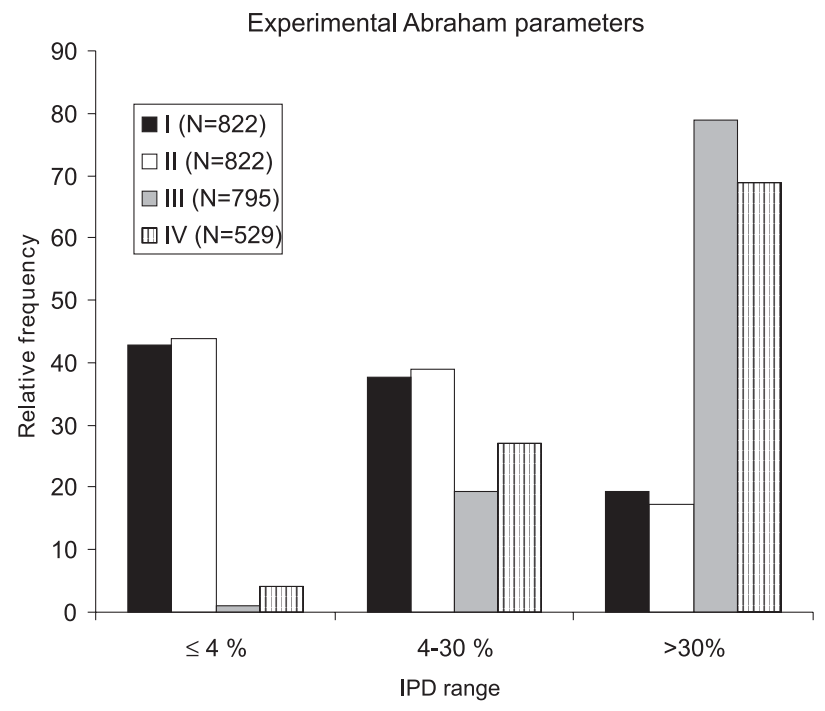

Figure 1. The relative frequency of the individual percentage deviations $(I P D)$ for various numerical analysis employing experimental Abraham parameters. 


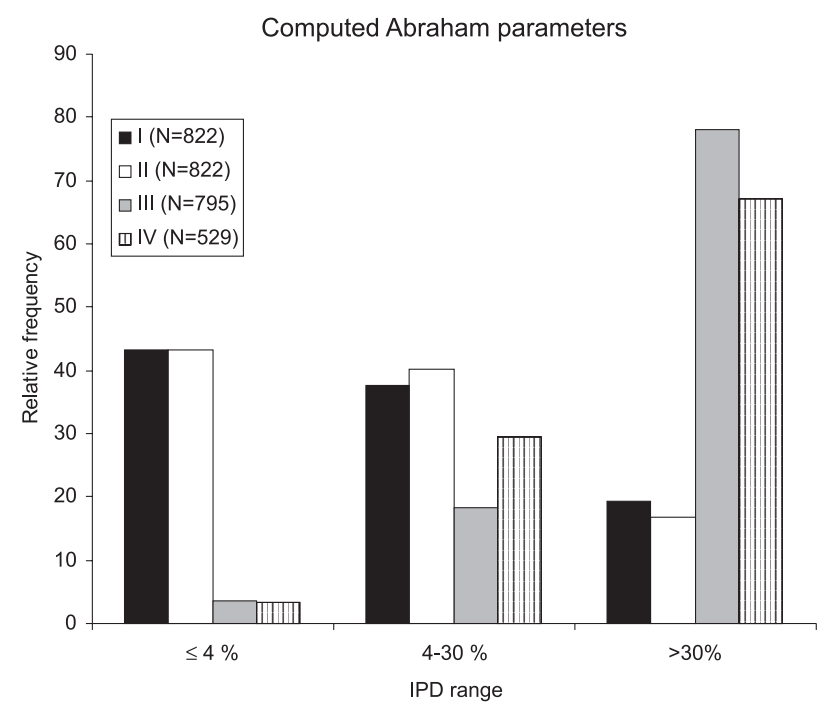

Figure 2. The relative frequency of the individual percentage deviations $(I P D)$ for various numerical analysis employing computed Abraham parameter.

the Jouyban-Acree model constants are not temperature dependent. The reason for this simplification was the shortage of the solubility data of solutes in non-aqueous binary solvents at various temperatures. The capability of the Jouyban-Acree model for calculating the solubility of solutes in binary solvents at various temperatures has been shown earlier. ${ }^{26}$

\section{Predictions using gas-to-solvent process and experimental solubility data in mono-solvents}

In the second set of calculations on the new data set, we computed the $B_{j}$ coefficients using equations (7)-(9) and experimentally-based Abraham solute descriptors. The calculated $B_{j}$ values were then combined with experimental $\ln X_{1}$ and $\ln X_{2}$ data to predict the mole fraction solubility $\ln X_{m}$ values for the 90 additional data sets (numerical method II of Table 1) using equation (3). The obtained MPD values are reported in column 3 of Table S5. The minimum $(0.2 \%)$ and maximum $(67.3 \%)$ MPDs were observed for p-benzoquinone in heptane + cyclohexane and for benzophenone in carbon tetrachloride + dodecane mixtures both at $25^{\circ} \mathrm{C}$. The overall $M P D( \pm \mathrm{SD})$ was $12.7 \pm 13.9 \%$. The same calculations were carried out using the computed Abraham parameters by PharmaAlgorithm software and the $M P D$ s were listed in the column 7 of Table S5). The minimum $(0.2 \%)$ and maximum $(68.4 \%) M P D$ s were observed for p-benzoquinone in heptane + cyclohexane and benzophenone in carbon tetrachloride + dodecane mixtures and the overall MPD $( \pm \mathrm{SD})$ was $12.5 \pm 13.7 \%$. There were i) no significant difference between 12.7 and $12.5 \%$ (paired $t$-test, $\mathrm{p}>0.05$ ), ii) the same frequency pattern for both $I P D$ s and iii) no difference between overall $M P D$ s for various solutes (see Figure S2) employing experimental and computed Abraham parameters, revealing that one can employ solute parameters computed by PharmaAlgorithm instead of their experimentally obtained values. Full agreement was observed from the results of the 90 and 194 data sets (see Table 2) and the relative frequency of IPDs was favorable.

Ab initio predictions using water-to-solvent process and computed solubility data in mono-solvents

In the third set of predictive calculations we again calculated the $B_{j}$ terms using equations (4)-(6) and the experimentally-based Abraham solute descriptors; however, in equation (3) the experimental mole fraction solubilities in the two mono-solvents were replaced with estimated $X_{1}$ and $X_{2}$ values based on equation (1). Results of these calculations are summarized in the fourth column of Table S5 for 86 of the 90 data sets considered. Predictions could not be made for the four p-tolylacetic acid systems because the molar solubility of p-tolylacetic acid in water, $\mathrm{C}_{\mathrm{w}}$, was not known. The molar solubility of the solute in water is a required input parameter in the estimation of solute's solubility in mono-solvents through equation (1). A minimum MPD of $11.2 \%$ was observed for naphthalene in benzene + toluene at $25^{\circ} \mathrm{C}$, and a maximum $M P D$ of $1811.2 \%$ was obtained for carbazole in octane + cyclohexane at $25^{\circ} \mathrm{C}$. The overall average $M P D$ was $228.7 \%$. The largest MPDs were observed for data set numbers 15-22 (benzoic acid), 29-44 (carbazole) and 77-82 (phenylacetic acid). Similar computations were performed using computed Abraham parameters for predicting $X_{1}, X_{2}$ and $B_{j}$ terms using the relevant equations. The $M P D$ values of these computations are listed in column 8 of Table S5. A nearly identical $M P D$ pattern was observed for data predicted by the experimental and computed parameters. The overall MPD was $168.9 \%$. Figure S3 showed overall $M P D$ for various solutes studied for experimental and computed parameters. This particular estimational scheme (method III) requires a prior knowledge of the solute's aqueous molar solubility, and based on the relatively large IPD and MPD between predicted and observed values the method did not provide a very reasonable prediction of the observed solubility behavior.

Ab initio predictions using gas-to-solvent process and computed solubility data in mono-solvents

Numerical method IV (see Table 1) involved using $B_{j}$ coefficiens based on equations (7)-(9), and estimated 
values for the solubility of the solute in both mon-solvents computed from equation (2). The minimum and maximum $M P D$ for method IV (see column 5 of Table S5) were 3.6 and $101.5 \%$, respectively, for naphthalene dissolved in benzene + toluene at $25{ }^{\circ} \mathrm{C}$ and for pyrene dissolved in toluene + heptane at $20{ }^{\circ} \mathrm{C}$ using experimentally-based Abraham solute descriptors. The overall MPD was 53.5 $( \pm 30.0) \%$. A slightly larger minimum $M P D$ of $5.6 \%$ (for naphthalene in carbon tetrachloride + hexane) and larger maximum $M P D$ of $197.5 \%$ (for pyrene in toluene + heptane at $20^{\circ} \mathrm{C}$ ) were obtained using computed Abraham solute descriptors. The overall MPD was also larger, $M P D=62.7 \%$, for the method IV predictions that used computed solute descriptors as input values (see column 9 of Table S5). As discussed above, the large deviations in binary solvents result mostly from the high IPDs of the solutes in mono-solvents (see Table S6 for details). It is difficult to accurately predict solubility in binary solvent mixtures when the inputted solubility data for the monosolvents that make up the binary solvent mixtures is poorly predicted. Better estimation methods for solute solubility in mono-solvents should allow one to reduce these deviations significantly.

\section{Conclusions}

Published methods for estimating the $B_{j}$ constants of the Jouyban-Acree model were applied successfully to a data set containing experimental solubility data for 90 additional solute-binary solvent-temperature combinations. None of the binary solvent solubility data was used in the regression analyses used to develop the predictive $B_{j}$ correlations. The predicted $B_{j}$ constants, when combined with experimental solubility data for the solute dissolved in the mono-solvents, enabled one to estimate the solubility of crystalline organic solutes in binary solvents using the Jouyban-Acree model. The expected prediction errors were $<14$ and $<13 \%$, respectively for water-to-solvent and gas-to-solvent coefficients employing both experimentally determined and theoretically calculated Abraham solute descriptors. The relatively small prediction errors indicate that it is possible to predict the solubility in binary solvents with minimum experimental efforts. Experimental solubility data exists in the published literature for many organic solutes in mono-solvents, and the Jouyban-Acree model allows one to quantitively estimate the extent to which cosolvency increases or decreases solute solubility. Such predictions are important in both solubilization and crystallization processes. Moreover, predictive methods, such as the Jouyban-Acree model, provide a convenient means to screen compiled experimental solubility data in order to detect possible outliers for re-determination. For any solubility datum with very high $I P D$, the remeasurement is recommended. The proposed methods could also be extended to predict the solubility in mixed solvents at various temperatures. We tried to develop an $a b$ initio prediction method employing $C_{W}$ or $C_{G}$ data of the solute (numerical methods III and IV); however, the obtained MPDs were $c a .200$ and $60 \%$.

As a practical conclusion, there are a number of possible solutions depending on the availability of the required input data: $i$ ) If the experimental solubility data of the solute in mono-solvent systems, i.e. $X_{1}$ and $X_{2}$, are available, the best solution to predict the solubility in mixed solvents is the numerical methods I or II and the expected prediction error is $c a .14 \%$. ii) If $X_{1}$ and $X_{2}$ are not available and the aqueous solubility of the solute is known, one could use the numerical method III and the expected prediction error is relatively high (170\%) for computed Abraham parameters. iii) If $X_{1}$ and $X_{2}$ are not available and $\mathrm{C}_{\mathrm{G}}$ of the solute is known, the numerical method IV could be a solution and the expected prediction error is slightly high ( $\mathrm{ca} .60 \%)$ for computed Abraham parameters.

\section{Supplemenatry Information}

Supplementary data are available free of charge at http://jbcs.sbq.org.br, as PDF file.

\section{Acknowledgments}

The financial support from Drug Applied Research Center (under grant number 85-64) was gratefully acknowledged. The authors also thank PharmaAlgorithm Inc. for the trial version of their software.

\section{References}

1. Abraham, M. H.; Green, C. E.; Acree, Jr., W. E.; Hernandez, C. E.; Roy, L. E.; J. Chem. Soc., Perkin Trans. 1998, 2, 2677.

2. Acree, Jr., W. E.; Abraham, M. H.; Can. J. Chem. 2001, 79, 1466.

3. Stovall, D. M.; Acree, Jr., W. E.; Abraham, M. H.; Fluid Phase Equilib. 2005, 232, 113.

4. Stovall., D. M.; Givens, C.; Keown, S.; Hoover, K. R.; Barnes, R.; Harris, C.; Lozano, J.; Nguyen, M.; Rodriguez, E.; Acree, Jr., W.E.; Abraham, M.H.; Phys. Chem. Liq. 2005, 43, 351.

5. Acree, Jr.,W. E.; Abraham, M. H.; Fluid Phase Equilib. 2002, 201, 245.

6. Acree, Jr., W. E.; Abraham, M. H.; J. Solution Chem. 2002, 31, 293.

7. Acree, Jr., W.E.; Thermochim. Acta 1992, 198, 71. 
8. Jouyban-Gharamaleki, A.; Valaee, L.; Barzegar-Jalali, M.; Clark, B.J. Acree, Jr., W.E.; Int. J. Pharm. 1999, 177, 93.

9. Jouyban, A.; Chan, H.K.; Chew, N. Y. K.; Khoubnasabjafari, M.; Acree, Jr., W. E.; Chem. Pharm. Bull. 2006, 54, 428.

10. Jouyban, A.; Acree, Jr., W. E.; Fluid Phase Equilib. 2006, 249, 24.

11. Al-Sharrah, G.K.; Ali, S.H.; Fahim, M.A.; Fluid Phase Equilib. 2002, 193, 191

12. Acree, Jr., W.E.; Bertrand, G.L.; J. Pharm. Sci. 1981, 70, 1033

13. Azizian, S.; Haydarpour, A.; J. Chem. Eng. Data 2003, 48, 1476

14. Acree, Jr., W.E.; Phys. Chem. Liq. 1990, 22, 157.

15. McCargar, J.W.; Acree, Jr., W.E.; Phys. Chem. Liq. 1987, 17, 123

16. Acree, Jr., W.E.; Tucker, S.A.; Int. J. Pharm. 1993, 101, 199.

17. McCargar, J.W.; Acree, Jr., W.E.; J. Pharm. Sci. 1987, 76, 572.

18. Heric, E.L.; Posey, C.D.; J. Chem. Eng. Data 1964, 9, 35.

19. Heric, E.L.; Posey, C.D.; J. Chem. Eng. Data 1965, 10, 25.

20. Heric, E.L.; Posey, C.D.; J. Chem. Eng. Data 1964, 9, 161.

21. Acree, Jr., W.E.; Rytting, J.H.; J. Pharm. Sci. 1982, 10, 231.
22. Judy, C.L.; Acree, Jr., W.E.; Int. J. Pharm. 1985, 27, 39.

23. Ali, S.H.; Al-Mutairi, F.S.; Fahim, M.A.; Fluid Phase Equilib. 2005, 230, 176.

24. Acree, Jr., W.E.; J. Chem. Eng. Data 1985, 30, 70.

25. PharmaAlgorithms, ADME Boxes, Version 3.0, PharmaAlgorithms Inc., 591 Indian Road, Toronto, ON M6P 2C4, Canada, 2006.

26. Jouyban, A.; Acree, Jr., W. E.; Fluid Phase Equilib. 2003, 209, 155

27. Abraham, M.H.; Zissimos, A.M.; Acree Jr., W.E.; Phys. Chem. Chem. Phys. 2001, 3, 3732.

28. Abraham, M.H.; Le, J.; J. Pharm. Sci. 1999, 88, 868.

29. Yalkowsky, S.H.; Valvani, S.C.; J. Pharm. Sci. 1980, 69, 912.

30. Abraham, M.H.; Le, J.; Acree, W.E.; Carr, P.W.; Dallas, A.J.; Chemosphere. 2001, 44, 855.

31. Yalkowsky, S.H.; He, Y.; Handbook of aqueous solubility data, CRC press, Florida, 2003.

32. Monte, M.J.S.; Hillesheim, D.M.; J. Chem. Eng. Data 2001, $46,1601$.

Received: August 23, 2007

Web Release Date: February 29, 2008 


\section{Solubility Prediction of Solutes in Non-Aqueous Binary Solvent Mixtures}

\section{Abolghasem Jouyban, ${ }^{*, a}$ Maryam Khoubnasabjafari, ${ }^{b}$ Somaieh Soltani, ${ }^{c}$ Shahla Soltanpour, ${ }^{d}$ Elnaz Tamizi ${ }^{e}$ and William E. Acree Jr. ${ }^{f}$}

${ }^{a}$ Faculty of Pharmacy and Drug Applied Research Center, Tabriz University of Medical Sciences, 51664, Iran

${ }^{b}$ Kimia Research Institute, P.O. Box 51665-171, Iran

${ }^{c}$ Research Center for Pharmaceutical Nanotechnology, Tabriz University of Medical Sciences, 51664, Iran

${ }^{d}$ Biotechnology Research Centre, Tabriz University of Medical Sciences, 51664, Iran

${ }^{e}$ Student Research Center, Tabriz University of Medical Sciences, 51664, Iran

${ }^{f}$ Department of Chemistry, University of North Texas, Denton, TX 76203-5070, USA

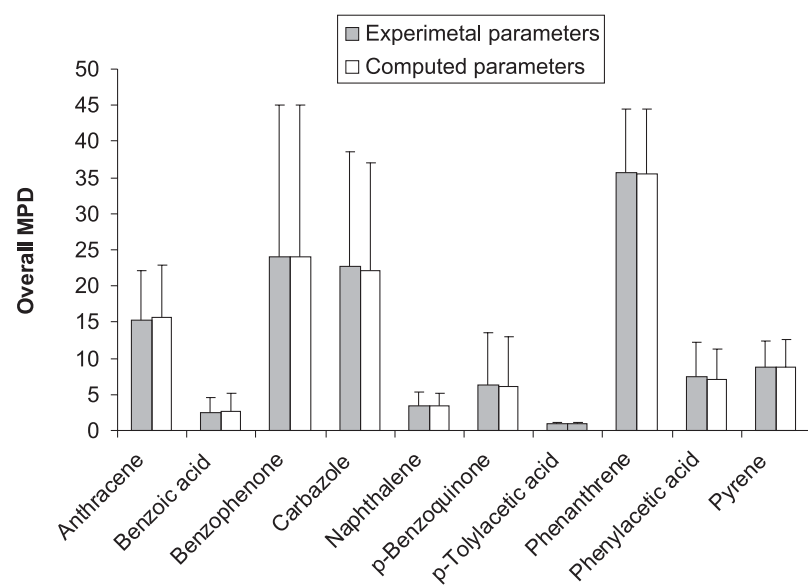

Figure S1. The overall MPD $( \pm \mathrm{SD})$ for numerical method I for various solutes

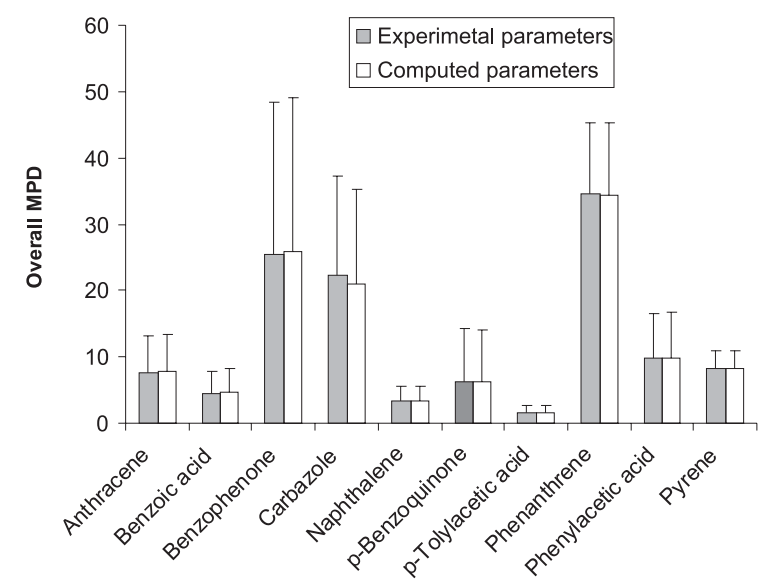

Figure S2. The overall MPD ( $\pm \mathrm{SD})$ for numerical method II for various solutes

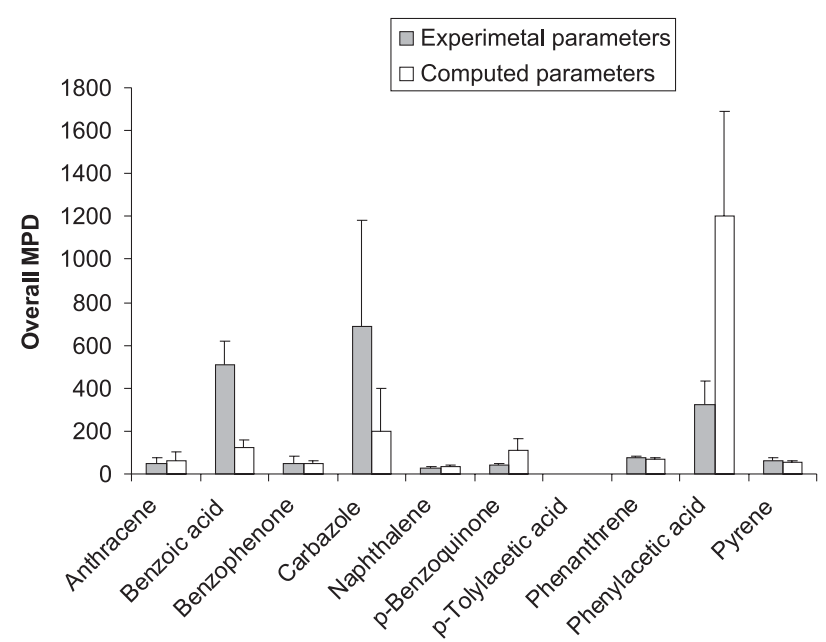

Figure S3. The overall MPD $( \pm \mathrm{SD})$ for numerical method III for various solutes

*e-mail: ajouyban@hotmail.com 
Table S1. Details of solutes and solvents names, the references of experimental data sets, logarithms of solubility in mono-solvents $\left(\ln X_{1}\right.$ and $\left.\ln X_{2}\right)$ and temperature $(T)$

\begin{tabular}{|c|c|c|c|c|c|c|c|c|}
\hline No. & Solute & Solvent 1 & Solvent 2 & $\mathrm{~N}$ & Reference & $\ln X_{\perp}$ & $\ln X_{2}$ & $T\left({ }^{\circ} \mathrm{C}\right)$ \\
\hline 1 & Anthracene & Toluene & 2-Propanol & 11 & 11 & -5.10 & -8.57 & 20 \\
\hline 2 & Anthracene & Toluene & 2-Propanol & 11 & 11 & -4.92 & -7.90 & 25 \\
\hline 3 & Anthracene & Toluene & 2-Propanol & 11 & 11 & -4.77 & -7.76 & 30 \\
\hline 4 & Anthracene & Toluene & 2-Propanol & 11 & 11 & -4.55 & -7.46 & 35 \\
\hline 5 & Anthracene & Toluene & 2-Propanol & 11 & 11 & -4.49 & -7.21 & 40 \\
\hline 6 & Anthracene & Toluene & 2-Propanol & 11 & 11 & -4.25 & -7.22 & 45 \\
\hline 7 & Anthracene & Toluene & 2-Propanol & 11 & 11 & -4.14 & -6.82 & 50 \\
\hline 8 & Anthracene & Toluene & Heptane & 10 & 11 & -5.05 & -6.72 & 20 \\
\hline 9 & Anthracene & Toluene & Heptane & 10 & 11 & -4.94 & -6.61 & 25 \\
\hline 10 & Anthracene & Toluene & Heptane & 10 & 11 & -4.77 & -6.29 & 30 \\
\hline 11 & Anthracene & Toluene & Heptane & 10 & 11 & -4.62 & -6.34 & 35 \\
\hline 12 & Anthracene & Toluene & Heptane & 10 & 11 & -4.51 & -6.05 & 40 \\
\hline 13 & Anthracene & Toluene & Heptane & 10 & 11 & -4.25 & -5.72 & 45 \\
\hline 14 & Anthracene & Toluene & Heptane & 10 & 11 & -4.23 & -5.68 & 50 \\
\hline 15 & Benzoic acid & Carbon tetrachloride & Cyclohexane & 7 & 12 & -3.01 & -4.47 & 25 \\
\hline 16 & Benzoic acid & Carbon tetrachloride & Heptane & 10 & 12 & -3.01 & -4.47 & 25 \\
\hline 17 & Benzoic acid & Carbon tetrachloride & Heptane & 6 & 12 & -2.82 & -4.22 & 30 \\
\hline 18 & Benzoic acid & Carbon tetrachloride & Hexane & 7 & 12 & -3.01 & -4.61 & 25 \\
\hline 19 & Benzoic acid & Carbon tetrachloride & Hexane & 7 & 12 & -2.82 & -4.37 & 30 \\
\hline 20 & Benzoic acid & Cyclohexane & Heptane & 7 & 12 & -4.47 & -4.47 & 25 \\
\hline 21 & Benzoic acid & Cyclohexane & Hexane & 7 & 12 & -4.47 & -4.61 & 25 \\
\hline 22 & Benzoic acid & Cyclohexane & Hexane & 7 & 12 & -4.23 & -4.37 & 30 \\
\hline 23 & Benzophenone & Carbon tetrachloride & Decane & 11 & 13 & -0.60 & -3.03 & 25 \\
\hline 24 & Benzophenone & Carbon tetrachloride & Dodecane & 11 & 13 & -0.60 & -3.54 & 25 \\
\hline 25 & Benzophenone & Carbon tetrachloride & Heptane & 11 & 13 & -0.60 & -3.16 & 25 \\
\hline 26 & Benzophenone & Carbon tetrachloride & Hexane & 9 & 13 & -0.60 & -3.75 & 25 \\
\hline 27 & Benzophenone & Carbon tetrachloride & Nonane & 11 & 13 & -0.60 & -2.81 & 25 \\
\hline 28 & Benzophenone & Carbon tetrachloride & Octane & 11 & 13 & -0.60 & -2.66 & 25 \\
\hline 30 & Carbazole & Cyclohexane & 2,2,4-Trimethylpentane & 11 & 14 & -8.61 & -8.98 & 25 \\
\hline 31 & Carbazole & Cyclohexane & Heptane & 9 & 14 & -8.61 & -8.66 & 25 \\
\hline 32 & Carbazole & Cyclohexane & Hexane & 9 & 14 & -8.61 & -8.88 & 25 \\
\hline 29 & Carbazole & Dibutylether & 2,2,4-Trimethylpentane & 9 & 15 & -5.30 & -8.98 & 25 \\
\hline 33 & Carbazole & Dibutylether & Cyclohexane & 11 & 16 & -5.30 & -8.61 & 25 \\
\hline 34 & Carbazole & Dibutylether & Heptane & 11 & 16 & -5.30 & -8.66 & 25 \\
\hline 35 & Carbazole & Dibutylether & Hexadecane & 11 & 17 & -5.30 & -7.79 & 25 \\
\hline 36 & Carbazole & Dibutylether & Hexane & 11 & 16 & -5.30 & -8.88 & 25 \\
\hline 37 & Carbazole & Dibutylether & Methylcyclohexane & 11 & 15 & -5.30 & -8.54 & 25 \\
\hline 38 & Carbazole & Dibutylether & Methylcyclohexane & 11 & 16 & -5.30 & -8.54 & 25 \\
\hline 39 & Carbazole & Dibutylether & n-Heptane & 11 & 15 & -5.30 & -8.66 & 25 \\
\hline 40 & Carbazole & Dibutylether & n-Hexane & 11 & 15 & -5.30 & -8.88 & 25 \\
\hline 41 & Carbazole & Dibutylether & n-Octane & 11 & 15 & -5.30 & -8.53 & 25 \\
\hline 42 & Carbazole & Dibutylether & Octane & 11 & 16 & -5.30 & -8.53 & 25 \\
\hline 43 & Carbazole & Methylcyclohexane & Cyclohexane & 9 & 14 & -8.54 & -8.61 & 25 \\
\hline 44 & Carbazole & Octane & Cyclohexane & 9 & 14 & -8.53 & -8.61 & 25 \\
\hline 45 & Naphthalene & Benzene & Carbon tetrachloride & 6 & 18 & -1.22 & -1.35 & 25 \\
\hline
\end{tabular}


Table S1. continuation

\begin{tabular}{|c|c|c|c|c|c|c|c|c|}
\hline No. & Solute & Solvent 1 & Solvent 2 & $\mathrm{~N}$ & Reference & $\ln X_{1}$ & $\ln X_{2}$ & $T\left({ }^{\circ} \mathrm{C}\right)$ \\
\hline 46 & Naphthalene & Benzene & Cyclohexane & 8 & 18 & -1.22 & -1.91 & 25 \\
\hline 47 & Naphthalene & Benzene & Hexadecane & 6 & 18 & -1.22 & -1.59 & 25 \\
\hline 48 & Naphthalene & Benzene & Hexane & 8 & 18 & -1.22 & -2.15 & 25 \\
\hline 49 & Naphthalene & Benzene & Toluene & 7 & 18 & -1.22 & -1.23 & 25 \\
\hline 50 & Naphthalene & Carbon tetrachloride & Cyclohexane & 6 & 19 & -1.35 & -1.91 & 25 \\
\hline 51 & Naphthalene & Carbon tetrachloride & Hexadecane & 6 & 19 & -1.35 & -1.59 & 25 \\
\hline 52 & Naphthalene & Carbon tetrachloride & Hexane & 8 & 19 & -1.35 & -2.15 & 25 \\
\hline 53 & Naphthalene & Cyclohexane & Hexane & 6 & 19 & -1.91 & -2.15 & 25 \\
\hline 54 & Naphthalene & Hexadecane & Cyclohexane & 7 & 19 & -1.59 & -1.91 & 25 \\
\hline 55 & Naphthalene & Hexadecane & Hexane & 6 & 19 & -1.59 & -2.15 & 25 \\
\hline 56 & Naphthalene & Toluene & Carbon tetrachloride & 6 & 20 & -1.23 & -1.35 & 25 \\
\hline 57 & Naphthalene & Toluene & Cyclohexane & 6 & 20 & -1.23 & -1.91 & 25 \\
\hline 58 & Naphthalene & Toluene & Hexadecane & 6 & 20 & -1.23 & -1.59 & 25 \\
\hline 59 & Naphthalene & Toluene & Hexane & 6 & 20 & -1.23 & -2.15 & 25 \\
\hline 60 & p-Benzoquinone & 2,2,4-Trimethylpentane & Cyclohexane & 7 & 21 & -5.01 & -5.03 & 25 \\
\hline 61 & p-Benzoquinone & Carbon tetrachloride & Heptane & 8 & 21 & -3.37 & -5.01 & 25 \\
\hline 62 & p-Benzoquinone & Carbon tetrachloride & Octane & 7 & 21 & -3.37 & -4.89 & 25 \\
\hline 63 & p-Benzoquinone & Dodecane & Heptane & 7 & 21 & -4.74 & -5.01 & 25 \\
\hline 64 & p-Benzoquinone & Heptane & Cyclohexane & 7 & 21 & -5.01 & -5.03 & 25 \\
\hline 65 & p-Tolylacetic acid & Cyclohexane & 2,2,4-Trimethylpentane & 7 & 22 & -4.32 & -4.83 & 25 \\
\hline 66 & p-Tolylacetic acid & Cyclohexane & Heptane & 7 & 22 & -4.30 & -4.78 & 25 \\
\hline 67 & p-Tolylacetic acid & Cyclohexane & Hexane & 8 & 22 & -4.32 & -4.85 & 25 \\
\hline 68 & p-Tolylacetic acid & Cyclohexane & Octane & 7 & 22 & -4.32 & -4.75 & 25 \\
\hline 69 & Phenanthrene & Toluene & 2,2,4-Trimethylpentane & 7 & 23 & -0.77 & -3.96 & 20 \\
\hline 70 & Phenanthrene & Toluene & 2,2,4-Trimethylpentane & 7 & 23 & -0.70 & -3.32 & 30 \\
\hline 71 & Phenanthrene & Toluene & 2,2,4-Trimethylpentane & 7 & 23 & -0.55 & -2.44 & 40 \\
\hline 72 & Phenanthrene & Toluene & 2,2,4-Trimethylpentane & 7 & 23 & -0.50 & -1.98 & 50 \\
\hline 73 & Phenanthrene & Toluene & Heptane & 11 & 23 & -0.77 & -4.17 & 20 \\
\hline 74 & Phenanthrene & Toluene & Heptane & 11 & 23 & -0.70 & -3.70 & 30 \\
\hline 75 & Phenanthrene & Toluene & Heptane & 11 & 23 & -0.55 & -3.32 & 40 \\
\hline 76 & Phenanthrene & Toluene & Heptane & 11 & 23 & -0.50 & -2.96 & 50 \\
\hline 77 & Phenylacetic acid & Carbon tetrachloride & 2,2,4-Trimethylpentane & 11 & 24 & -1.75 & -4.40 & 25 \\
\hline 78 & Phenylacetic acid & Carbon tetrachloride & Cyclohexane & 11 & 24 & -1.75 & -3.70 & 25 \\
\hline 79 & Phenylacetic acid & Carbon tetrachloride & Heptane & 11 & 24 & -1.75 & -4.31 & 25 \\
\hline 80 & Phenylacetic acid & Carbon tetrachloride & Octane & 11 & 24 & -1.75 & -4.24 & 25 \\
\hline 81 & Phenylacetic acid & Cyclohexane & 2,2,4-Trimethylpentane & 9 & 24 & -3.70 & -4.40 & 25 \\
\hline 82 & Phenylacetic acid & Cyclohexane & Heptane & 8 & 24 & -3.70 & -4.31 & 25 \\
\hline 83 & Pyrene & Toluene & 2,2,4-Trimethylpentane & 12 & 20 & -2.87 & -4.72 & 20 \\
\hline 84 & Pyrene & Toluene & 2,2,4-Trimethylpentane & 12 & 20 & -2.41 & -4.47 & 30 \\
\hline 85 & Pyrene & Toluene & 2,2,4-Trimethylpentane & 12 & 20 & -2.21 & -4.37 & 40 \\
\hline 86 & Pyrene & Toluene & 2,2,4-Trimethylpentane & 12 & 20 & -1.57 & -3.94 & 50 \\
\hline 87 & Pyrene & Toluene & Heptane & 11 & 20 & -2.87 & -4.47 & 20 \\
\hline 88 & Pyrene & Toluene & Heptane & 11 & 20 & -2.41 & -4.17 & 30 \\
\hline 89 & Pyrene & Toluene & Heptane & 11 & 20 & -2.21 & -3.63 & 40 \\
\hline 90 & Pyrene & Toluene & Heptane & 11 & 20 & -1.57 & -3.01 & 50 \\
\hline
\end{tabular}


Table S2. Coefficients in equations (1) and (2) for water-to-solvent and gas-to-solvent processes of the solvents used in this study ${ }^{\mathrm{a}}$

\begin{tabular}{|c|c|c|c|c|c|c|c|}
\hline No. & Water-to-solvent coefficients & $\mathrm{c}$ & $\mathrm{e}$ & $\mathrm{s}$ & $\mathrm{a}$ & $\mathrm{b}$ & $\mathrm{v}$ \\
\hline 1 & 2,2,4-Trimethylpentane & 0.288 & 0.382 & -1.668 & -3.639 & -5.000 & 4.461 \\
\hline 2 & 2-Propanol & 0.063 & 0.320 & -1.024 & 0.445 & -3.824 & 4.067 \\
\hline 3 & Benzene & 0.142 & 0.464 & -0.588 & -3.099 & -4.625 & 4.491 \\
\hline 4 & Carbone tetrachloride & 0.260 & 0.573 & -1.254 & -3.558 & -4.558 & 4.589 \\
\hline 5 & Cyclohexane & 0.159 & 0.784 & -1.678 & -3.740 & -4.929 & 4.577 \\
\hline 6 & Decane & 0.160 & 0.585 & -1.730 & -3.440 & -5.080 & 4.582 \\
\hline 7 & Dibutyl ether & 0.203 & 0.369 & -0.954 & -1.488 & -5.426 & 4.508 \\
\hline 8 & Dodecane & 0.114 & 0.668 & -1.640 & -3.550 & -5.010 & 4.459 \\
\hline 9 & Heptane & 0.325 & 0.670 & -2.061 & -3.317 & -4.733 & 4.543 \\
\hline 10 & Hexadecane & 0.087 & 0.667 & -1.620 & -3.59 & -4.870 & 4.433 \\
\hline 11 & Hexane & 0.361 & 0.579 & -1.723 & -3.599 & -4.764 & 4.344 \\
\hline 12 & Methylcyclohexane & 0.246 & 0.782 & -1.982 & -3.517 & -4.293 & 4.528 \\
\hline 13 & Nonane & 0.240 & 0.619 & -1.710 & -3.530 & -4.920 & 4.482 \\
\hline 14 & Octane & 0.223 & 0.642 & -1.647 & -3.480 & -5.067 & 4.526 \\
\hline 15 & Toluene & 0.143 & 0.527 & -0.720 & -3.010 & -4.824 & 4.545 \\
\hline No. & Gas-to-solvent coefficients & $\mathrm{c}$ & $\mathrm{e}$ & $\mathrm{s}$ & $\mathrm{a}$ & $\mathrm{b}$ & 1 \\
\hline 1 & 2,2,4-Trimethylpentane & 0.275 & -0.244 & 0.000 & 0.000 & 0.000 & 0.972 \\
\hline 2 & 2-Propanol & -0.060 & -0.335 & 0.702 & 4.017 & 1.040 & 0.893 \\
\hline 3 & Benzene & 0.107 & -0.313 & 1.053 & 0.457 & 0.169 & 1.020 \\
\hline 4 & Carbone tetrachloride & 0.282 & -0.303 & 0.460 & 0.000 & 0.000 & 1.047 \\
\hline 5 & Cyclohexane & 0.163 & -0.110 & 0.000 & 0.000 & 0.000 & 1.013 \\
\hline 6 & Decane & 0.156 & -0.140 & 0.000 & 0.000 & 0.000 & 0.989 \\
\hline 7 & Dibutyl ether & 0.165 & -0.421 & 0.760 & 2.102 & -0.664 & 1.002 \\
\hline 8 & Dodecane & 0.053 & 0.000 & 0.000 & 0.000 & 0.000 & 0.986 \\
\hline 9 & Heptane & 0.275 & -0.162 & 0.000 & 0.000 & 0.000 & 0.983 \\
\hline 10 & Hexadecane & 0.000 & 0.000 & 0.000 & 0.000 & 0.000 & 1.000 \\
\hline 11 & Hexane & 0.292 & -0.169 & 0.000 & 0.000 & 0.000 & 0.979 \\
\hline 12 & Methylcyclohexane & 0.318 & -0.215 & 0.000 & 0.000 & 0.000 & 1.012 \\
\hline 13 & Nonane & 0.200 & -0.145 & 0.000 & 0.000 & 0.000 & 0.980 \\
\hline 14 & Octane & 0.215 & -0.049 & 0.000 & 0.000 & 0.000 & 0.967 \\
\hline 15 & Toluene & 0.121 & -0.222 & 0.938 & 0.467 & 0.099 & 1.012 \\
\hline
\end{tabular}

${ }^{a}$ Data taken from a reference ${ }^{5}$

Table S3. The experimental and computed Abraham parameters along with the input properties for solutes studied in this work and their references

\begin{tabular}{|c|c|c|c|c|c|c|c|c|c|}
\hline \multirow[t]{2}{*}{ Solute } & $\mathrm{E}$ & $\mathrm{S}$ & $A$ & $B$ & $V$ & $L$ & $\log C_{W}$ & $\log C_{G}$ & Reference \\
\hline & \multicolumn{9}{|c|}{ Experimental Abraham parameters } \\
\hline Anthracene & 2.290 & 1.34 & 0.000 & 0.280 & & 7.568 & -6.430 & -9.460 & 2 \\
\hline Benzoic acid & 0.730 & 0.90 & 0.590 & 0.400 & & 4.395 & -1.550 & -6.690 & 27 \\
\hline Benzophenone & 1.447 & 1.50 & 0.000 & 0.500 & & 6.852 & $-3.120^{28}$ & $-{ }^{\mathrm{a}}$ & 25 \\
\hline Carbazole & 1.787 & 2.01 & 0.180 & 0.080 & & 7.982 & $-5.270^{28}$ & $-{ }^{\mathrm{a}}$ & 25 \\
\hline Naphthalene & 1.340 & 0.92 & 0.000 & 0.200 & & 5.161 & $-3.610^{29}$ & -5.340 & 30 \\
\hline p-Benzoquinone & 0.750 & 0.55 & 0.000 & 0.810 & & 3.492 & $-0.880^{31}$ & $-{ }^{\mathrm{a}}$ & 25 \\
\hline p-Tolylacetic acid & 0.730 & 0.97 & 0.600 & 0.640 & & 5.480 & $-{ }^{\mathrm{a}}$ & $-{ }^{\mathrm{a}}$ & 25 \\
\hline Phenanthrene & 2.055 & 1.29 & 0.000 & 0.290 & & 7.632 & -5.170 & -7.970 & 2 \\
\hline Phenylacetic acid & 0.730 & 1.01 & 0.590 & 0.610 & & 4.933 & $-0.890^{28}$ & $-7.562^{\mathrm{b}}$ & 25 \\
\hline \multirow[t]{2}{*}{ Pyrene } & 2.808 & 1.71 & 0.000 & 0.280 & & 8.833 & -6.150 & -9.650 & 5 \\
\hline & \multicolumn{9}{|c|}{ Computed Abraham parameters } \\
\hline Anthracene & 1.99 & 1.34 & 0.000 & 0.23 & 1.454 & 7.706 & & & 25 \\
\hline Benzoic acid & 0.75 & 1.08 & 0.570 & 0.44 & 0.932 & 4.533 & & & 25 \\
\hline Benzophenone & 1.37 & 1.59 & 0.000 & 0.51 & 1.481 & 7.308 & & & 25 \\
\hline Carbazole & 1.94 & 1.43 & 0.310 & 0.39 & 1.315 & 7.869 & & & 25 \\
\hline Naphthalene & 1.27 & 1.02 & 0.000 & 0.17 & 1.085 & 5.332 & & & 25 \\
\hline p-Benzoquinone & 0.90 & 0.43 & 0.000 & 0.76 & 0.791 & 3.500 & & & 25 \\
\hline p-Tolylacetic acid & 0.77 & 1.02 & 0.570 & 0.45 & 1.214 & 5.499 & & & 25 \\
\hline Phenanthrene & 1.99 & 1.34 & 0.000 & 0.23 & 1.454 & 7.706 & & & 25 \\
\hline Phenylacetic acid & 0.75 & 1.08 & 0.570 & 0.45 & 1.073 & 5.028 & & & 25 \\
\hline Pyrene & 2.60 & 1.52 & 0.000 & 0.25 & 1.585 & 9.110 & & & 25 \\
\hline
\end{tabular}

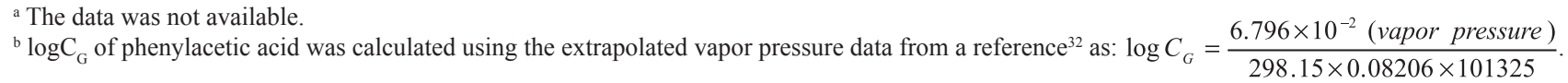


Table S4. The individual percentage deviations (IPDs) of solubilities of solutes ${ }^{10}$ in some of the solvents predicted by equations (1) and (2) employing experimental and computed Abraham parameters

\begin{tabular}{|c|c|c|c|c|c|c|}
\hline \multirow{2}{*}{ Solute $^{\mathrm{a}}$} & \multirow{2}{*}{ Solvent $^{\mathrm{a}}$} & \multirow[t]{2}{*}{$T\left({ }^{\circ} \mathrm{C}\right)$} & \multicolumn{2}{|c|}{ Experimental parameters } & \multicolumn{2}{|c|}{ Computed parameters } \\
\hline & & & Equation (1) & Equation (2) & Equation (1) & Equation (2) \\
\hline Anthracene & 1,4-Dioxane & 25 & 20.5 & 20.0 & 64.4 & 36.1 \\
\hline Anthracene & 1-Butanol & 25 & 25.5 & 1.0 & 45.6 & 43.7 \\
\hline Anthracene & 1-Octanol & 25 & 17.0 & 23.9 & 35.7 & 8.8 \\
\hline Anthracene & 1-Pentanol & 25 & 34.4 & 21.9 & 47.0 & 13.5 \\
\hline Anthracene & 2,2,4-Trimethylpentane & 25 & 40.3 & 36.3 & 18.5 & 2.6 \\
\hline Anthracene & 2-Butanol & 25 & 21.2 & 24.0 & 55.6 & 22.8 \\
\hline Anthracene & 2-Methyl-1-propanol & 25 & 37.7 & 11.7 & 64.8 & 34.1 \\
\hline Anthracene & 2-Propanol & 25 & 28.5 & 5.4 & 60.0 & 40.4 \\
\hline Anthracene & Acetonitrile & 25 & 14.6 & 6.3 & 80.0 & 70.1 \\
\hline Anthracene & Benzene & 25 & 97.7 & 52.7 & 143.6 & 155.2 \\
\hline Anthracene & Carbon tetrachloride & 25 & 49.3 & 3.3 & 69.7 & 65.7 \\
\hline Anthracene & Cyclohexane & 25 & 149.6 & 7.7 & 156.1 & 37.3 \\
\hline Anthracene & Dibutyl ether & 25 & 11.5 & 32.4 & 61.2 & 33.8 \\
\hline Anthracene & Heptane & 25 & 16.7 & 28.2 & 9.6 & 9.7 \\
\hline Anthracene & Hexane & 25 & 12.0 & 26.2 & 2.0 & 13.2 \\
\hline Anthracene & Methanol & 25 & 3.2 & 1.8 & 24.0 & 27.9 \\
\hline Anthracene & Methyl tert-buthyl ether & 25 & 22.6 & 24.6 & 82.0 & 44.6 \\
\hline Anthracene & Methylcyclohexane & 25 & 66.8 & 17.8 & 59.4 & 31.4 \\
\hline Anthracene & Octane & 25 & 46.8 & 18.7 & 68.8 & 14.3 \\
\hline Anthracene & Toluene & 25 & 132.9 & 78.7 & 181.0 & 182.0 \\
\hline Benzil & 1-Butanol & 25 & 5.3 & 15.8 & 94.8 & 1599.5 \\
\hline Benzil & 1-Octanol & 25 & 60.1 & 29.0 & 91.8 & 1540.8 \\
\hline Benzil & 1-Pentanol & 25 & 10.9 & 95.6 & 95.1 & 1421.3 \\
\hline Benzil & 1-Propanol & 25 & 5.7 & 25.1 & 94.9 & 1146.8 \\
\hline Benzil & 2,2,4-Trimethylpentane & 25 & 38.2 & 29.4 & 99.0 & 375.6 \\
\hline Benzil & 2-Butanol & 25 & 46.5 & 32.3 & 91.0 & 2172.1 \\
\hline Benzil & 2-Propanol & 25 & 25.4 & 14.0 & 92.6 & 1882.9 \\
\hline Benzil & Carbon tetrachloride & 25 & 38.6 & 51.6 & 97.8 & 337.6 \\
\hline Benzil & Cyclohexane & 25 & 4.2 & 36.7 & 98.0 & 373.9 \\
\hline Benzil & Heptane & 25 & 34.2 & 10.9 & 99.1 & 521.9 \\
\hline Benzil & Octane & 25 & 25.6 & 14.2 & 97.7 & 498.8 \\
\hline Pyrene & 1-Butanol & 26 & 33.8 & 42.0 & 17.2 & 115.8 \\
\hline Pyrene & 1-Octanol & 26 & 39.8 & 1.9 & 0.0 & 45.3 \\
\hline Pyrene & 1-Pentanol & 26 & 34.0 & 43.1 & 18.1 & 16.8 \\
\hline Pyrene & 1-Propanol & 26 & 21.2 & 13.8 & 35.0 & 26.1 \\
\hline Pyrene & 2,2,4-Trimethylpentane & 26 & 75.4 & 23.1 & 40.1 & 59.7 \\
\hline Pyrene & 2-Butanol & 26 & 36.8 & 2.8 & 11.0 & 50.2 \\
\hline Pyrene & 2-Methyl-1-propanol & 26 & 26.4 & 21.0 & 29.4 & 77.3 \\
\hline Pyrene & 2-Propanol & 26 & 27.7 & 41.5 & 26.2 & 100.7 \\
\hline Pyrene & Benzene & 26 & 64.4 & 210.3 & 124.4 & 300.3 \\
\hline Pyrene & Cyclohexane & 26 & 59.5 & 38.1 & 215.3 & 173.6 \\
\hline Pyrene & Dibutyl ether & 26 & 32.0 & 9.7 & 23.6 & 86.4 \\
\hline Pyrene & Heptane & 26 & 66.0 & 5.7 & 16.1 & 88.8 \\
\hline Pyrene & Hexane & 26 & 57.4 & 0.0 & 5.2 & 100.7 \\
\hline Pyrene & Methylcyclohexane & 26 & 25.8 & 1.2 & 61.5 & 105.9 \\
\hline Pyrene & Octane & 26 & 23.5 & 8.7 & 62.1 & 103.4 \\
\hline Thianthrene & 2,2,4-Trimethylpentane & 25 & 45.2 & 27.1 & 71.1 & 112.5 \\
\hline Thianthrene & Cyclohexane & 25 & 53.1 & 22.9 & 29.4 & 121.9 \\
\hline Thianthrene & Heptane & 25 & 12.3 & 3.1 & 56.2 & 176.4 \\
\hline Thianthrene & Hexane & 25 & 17.7 & 12.6 & 58.4 & 149.3 \\
\hline Thianthrene & Methylcyclohexane & 25 & 8.3 & 31.8 & 45.5 & 103.9 \\
\hline
\end{tabular}


Table S4. continuation

\begin{tabular}{|c|c|c|c|c|c|c|}
\hline \multirow{2}{*}{ Solute $^{\mathrm{a}}$} & \multirow{2}{*}{ Solvent $^{\mathrm{a}}$} & \multirow[t]{2}{*}{$T\left({ }^{\circ} \mathrm{C}\right)$} & \multicolumn{2}{|c|}{ Experimental parameters } & \multicolumn{2}{|c|}{ Computed parameters } \\
\hline & & & Equation (1) & Equation (2) & Equation (1) & Equation (2) \\
\hline Thianthrene & Octane & 25 & 57.1 & 7.7 & 25.1 & 189.8 \\
\hline Trans-Stilbene & 1-Propanol & 25 & 23.4 & 10.8 & 33.9 & 57.4 \\
\hline Trans-Stilbene & 2,2,4-Trimethylpentane & 25 & 22.2 & 9.5 & 16.7 & 63.0 \\
\hline Trans-Stilbene & 2-Butanol & 25 & 53.2 & 28.5 & 79.9 & 32.5 \\
\hline Trans-Stilbene & Cyclohexane & 25 & 32.2 & 14.5 & 22.7 & 67.7 \\
\hline Trans-Stilbene & Heptane & 25 & 6.0 & 5.4 & 23.9 & 62.6 \\
\hline Trans-Stilbene & Hexane & 25 & 17.7 & 8.7 & 22.0 & 63.7 \\
\hline Trans-Stilbene & Methylcyclohexane & 25 & 21.4 & 4.3 & 8.8 & 62.5 \\
\hline Trans-Stilbene & Octane & 25 & 27.2 & 11.9 & 27.5 & 65.9 \\
\hline \multirow[t]{3}{*}{ Anthracene } & 1,4-Dioxane & 25 & 20.5 & 20.0 & 64.4 & 36.1 \\
\hline & & All & $36.3^{\mathrm{b}}$ & $24.4^{\mathrm{c}}$ & $59.7^{\mathrm{b}}$ & $262.8^{\mathrm{c}}$ \\
\hline & & 25 & $34.6^{\mathrm{d}}$ & $22.2^{\mathrm{e}}$ & $64.5^{\mathrm{d}}$ & $319.4^{\mathrm{e}}$ \\
\hline
\end{tabular}

${ }^{\mathrm{a}}$ Details of the references of data were reported in an earlier work. ${ }^{10}{ }^{\mathrm{b}}{ }^{\mathrm{b}}$ The difference was statistically significant (paired t-test, $\mathrm{p}<0.0005$ ); ${ }^{\mathrm{c}}$ The difference was statistically significant (paired t-test, $\mathrm{p}<0.0005$ ); ${ }^{\mathrm{d}}$ The difference was statistically significant (paired t-test, $\mathrm{p}<0.0005$ ); ${ }^{\mathrm{e}}$ The difference was statistically significant (paired t-test, $\mathrm{p}>0.001$ ).

Table S5. The mean percentage deviation $(M P D)$ of various numerical analyses employing the experimental and computed Abraham parameters of the solutes and the overall $( \pm \mathrm{SD})$ of $M P D$ s

\begin{tabular}{|c|c|c|c|c|c|c|c|c|}
\hline \multirow{2}{*}{$\begin{array}{l}\text { Numerical method } \\
\text { No. }^{\text {a }}\end{array}$} & I & II & III & IV & I & II & III & IV \\
\hline & \multicolumn{4}{|c|}{ Experimental Abraham parameters } & \multicolumn{4}{|c|}{ Computed Abraham parameters } \\
\hline 1 & 30.3 & 18.2 & 95.8 & 72.9 & 31.0 & 18.7 & 138.0 & 161.3 \\
\hline 2 & 18.3 & 3.6 & 45.2 & 28.8 & 19.1 & 4.1 & 76.4 & 94.8 \\
\hline 3 & 17.7 & 4.5 & 27.1 & 17.6 & 18.6 & 5.0 & 53.5 & 69.8 \\
\hline 4 & 16.9 & 1.6 & 23.0 & 21.1 & 17.8 & 1.9 & 22.5 & 32.3 \\
\hline 5 & 15.9 & 3.8 & 29.5 & 28.9 & 16.7 & 4.1 & 24.3 & 24.2 \\
\hline 6 & 22.2 & 7.3 & 33.2 & 37.5 & 23.0 & 8.0 & 26.2 & 20.8 \\
\hline 7 & 16.5 & 2.2 & 43.3 & 48.5 & 17.3 & 2.5 & 36.0 & 30.0 \\
\hline 8 & 16.9 & 14.8 & 112.2 & 68.2 & 16.9 & 14.8 & 145.8 & 160.0 \\
\hline 9 & 11.6 & 9.7 & 79.3 & 44.0 & 11.6 & 9.7 & 106.8 & 119.1 \\
\hline 10 & 16.1 & 14.2 & 52.7 & 27.3 & 16.1 & 14.2 & 74.8 & 81.5 \\
\hline 11 & 2.7 & 2.2 & 34.2 & 23.1 & 2.7 & 2.2 & 47.8 & 49.6 \\
\hline 12 & 5.7 & 4.4 & 32.0 & 26.9 & 5.7 & 4.4 & 41.3 & 39.9 \\
\hline 13 & 16.0 & 13.9 & 26.2 & 31.9 & 16.0 & 14.0 & 31.5 & 27.9 \\
\hline 14 & 7.6 & 5.9 & 28.5 & 38.8 & 7.6 & 6.0 & 31.1 & 27.1 \\
\hline 15 & 0.8 & 0.7 & 493.7 & 94.4 & 0.7 & 0.6 & 135.8 & 91.5 \\
\hline 16 & 6.5 & 10.0 & 460.9 & 93.4 & 7.2 & 10.5 & 115.4 & 90.0 \\
\hline 17 & 5.1 & 8.4 & 357.9 & 94.6 & 5.6 & 8.8 & 69.6 & 92.0 \\
\hline 18 & 2.1 & 5.3 & 510.0 & 93.5 & 2.3 & 5.7 & 141.0 & 90.3 \\
\hline 19 & 2.6 & 5.2 & 386.3 & 94.8 & 2.8 & 5.5 & 91.8 & 92.2 \\
\hline 20 & 1.0 & 1.5 & 626.6 & 92.9 & 0.8 & 1.5 & 138.3 & 90.3 \\
\hline 21 & 0.5 & 1.7 & 697.2 & 92.9 & 0.5 & 1.7 & 176.4 & 90.3 \\
\hline 22 & 0.7 & 2.1 & 527.9 & 94.4 & 0.7 & 2.1 & 117.5 & 92.3 \\
\hline 23 & 6.9 & 8.9 & 23.9 & - & 7.0 & 9.5 & 43.5 & - \\
\hline 24 & 61.6 & 67.3 & 114.6 & - & 61.8 & 68.4 & 43.1 & - \\
\hline 25 & 15.0 & 13.9 & 37.9 & - & 14.9 & 13.8 & 62.4 & - \\
\hline 26 & 34.8 & 36.8 & 37.4 & - & 34.9 & 37.2 & 25.1 & - \\
\hline 27 & 7.4 & 10.7 & 25.8 & - & 7.4 & 11.2 & 47.9 & - \\
\hline 28 & 18.1 & 15.4 & 38.4 & - & 18.0 & 15.4 & 59.2 & - \\
\hline 29 & 34.9 & 31.7 & 324.3 & - & 34.8 & 29.8 & 53.1 & - \\
\hline 30 & 0.9 & 4.5 & 1291.2 & - & 0.9 & 4.4 & 370.3 & - \\
\hline 31 & 0.9 & 0.8 & 1011.5 & - & 0.9 & 0.8 & 409.3 & - \\
\hline 32 & 1.7 & 0.8 & 1355.5 & - & 1.9 & 0.8 & 461.7 & - \\
\hline 33 & 41.4 & 39.4 & 596.9 & - & 41.1 & 38.0 & 118.1 & - \\
\hline 34 & 28.2 & 29.8 & 231.9 & - & 27.7 & 27.9 & 50.6 & - \\
\hline 35 & 16.7 & 14.3 & 528.2 & - & 15.6 & 11.9 & 65.3 & - \\
\hline
\end{tabular}


Table S5. Cont.

\begin{tabular}{|c|c|c|c|c|c|c|c|c|}
\hline \multirow{2}{*}{$\begin{array}{l}\text { Numerical method } \\
\text { No. }{ }^{\text {a }}\end{array}$} & I & II & III & IV & I & II & III & IV \\
\hline & \multicolumn{4}{|c|}{ Experimental Abraham parameters } & \multicolumn{4}{|c|}{ Computed Abraham parameters } \\
\hline 36 & 35.5 & 34.5 & 348.6 & - & 34.4 & 32.9 & 61.1 & - \\
\hline 37 & 36.2 & 37.2 & 282.8 & - & 32.2 & 35.8 & 87.7 & - \\
\hline 38 & 35.6 & 36.6 & 268.2 & - & 31.0 & 35.0 & 87.3 & - \\
\hline 39 & 28.2 & 29.8 & 231.9 & - & 27.7 & 27.9 & 50.6 & - \\
\hline 40 & 35.5 & 34.5 & 349.0 & - & 34.3 & 32.8 & 61.2 & - \\
\hline 41 & 32.2 & 28.3 & 581.9 & - & 32.3 & 26.4 & 83.7 & - \\
\hline 42 & 32.2 & 28.3 & 581.9 & - & 32.3 & 26.4 & 83.7 & - \\
\hline 43 & 2.2 & 0.6 & 1208.1 & - & 5.3 & 0.6 & 602.1 & - \\
\hline 44 & 1.3 & 3.3 & 1811.2 & - & 1.1 & 3.3 & 547.9 & - \\
\hline 45 & 2.4 & 3.5 & 23.1 & 16.3 & 2.6 & 3.7 & 21.3 & 30.7 \\
\hline 46 & 4.7 & 3.5 & 26.5 & 31.5 & 4.3 & 3.1 & 28.6 & 22.7 \\
\hline 47 & 1.9 & 4.1 & 26.8 & 12.8 & 2.2 & 4.6 & 29.5 & 26.8 \\
\hline 48 & 5.4 & 4.2 & 36.7 & 27.6 & 5.0 & 3.8 & 38.0 & 18.2 \\
\hline 49 & 1.1 & 1.3 & 11.2 & 3.6 & 1.1 & 1.4 & 4.7 & 48.6 \\
\hline 50 & 1.9 & 0.7 & 32.4 & 39.1 & 2.0 & 0.5 & 39.3 & 11.2 \\
\hline 51 & 6.0 & 8.4 & 30.3 & 17.5 & 6.0 & 8.5 & 36.9 & 18.4 \\
\hline 52 & 2.0 & 1.1 & 42.0 & 33.2 & 2.0 & 1.4 & 47.7 & 5.6 \\
\hline 53 & 1.1 & 0.3 & 37.6 & 41.7 & 1.1 & 0.3 & 46.5 & 15.1 \\
\hline 54 & 6.4 & 6.2 & 28.3 & 25.7 & 6.4 & 6.2 & 37.4 & 11.0 \\
\hline 55 & 4.7 & 2.6 & 36.7 & 25.6 & 4.7 & 2.7 & 44.7 & 7.5 \\
\hline 56 & 2.1 & 3.4 & 18.7 & 12.3 & 2.1 & 3.6 & 17.9 & 34.2 \\
\hline 57 & 5.1 & 3.3 & 22.3 & 27.5 & 4.7 & 3.0 & 25.0 & 23.5 \\
\hline 58 & 2.1 & 3.6 & 23.1 & 9.9 & 2.3 & 4.0 & 26.4 & 29.2 \\
\hline 59 & 5.2 & 5.1 & 32.7 & 24.7 & 4.8 & 4.7 & 34.7 & 18.2 \\
\hline 60 & 0.2 & 1.1 & 45.5 & - & .2 & 1.1 & 88.3 & - \\
\hline 61 & 10.0 & 12.7 & 42.0 & - & 9.5 & 12.5 & 96.1 & - \\
\hline 62 & 17.2 & 17.0 & 52.5 & - & 16.6 & 16.7 & 51.4 & - \\
\hline 63 & 3.3 & 0.3 & 28.9 & - & 3.1 & 0.3 & 160.3 & - \\
\hline 64 & 1.0 & 0.2 & 27.7 & - & .9 & 0.2 & 167.5 & - \\
\hline 65 & 1.1 & 0.7 & - & - & 1.1 & 0.7 & - & - \\
\hline 66 & 1.1 & 0.5 & - & - & 1.0 & 0.5 & - & - \\
\hline 67 & 0.9 & 2.6 & - & - & 1.0 & 2.6 & - & - \\
\hline 68 & 0.5 & 2.3 & - & - & 0.5 & 2.3 & - & - \\
\hline 69 & 36.0 & 33.4 & 70.1 & 40.3 & 35.9 & 33.3 & 54.8 & 35.2 \\
\hline 70 & 31.2 & 28.3 & 77.3 & 49.9 & 31.1 & 28.1 & 65.8 & 39.0 \\
\hline 71 & 26.5 & 23.3 & 84.5 & 66.9 & 26.4 & 23.1 & 76.7 & 59.8 \\
\hline 72 & 20.3 & 16.7 & 86.1 & 70.8 & 20.2 & 16.4 & 79.1 & 64.4 \\
\hline 73 & 42.2 & 43.0 & 61.7 & 55.2 & 42.1 & 42.9 & 52.4 & 53.0 \\
\hline 74 & 45.1 & 45.8 & 71.3 & 56.0 & 44.9 & 45.7 & 59.6 & 50.4 \\
\hline 75 & 43.3 & 44.1 & 77.1 & 58.2 & 43.1 & 43.9 & 67.4 & 53.1 \\
\hline 76 & 40.5 & 41.4 & 80.3 & 61.9 & 40.3 & 41.2 & 71.8 & 54.0 \\
\hline 77 & 11.4 & 16.5 & 274.9 & 98.3 & 10.4 & 16.8 & 994.3 & 97.9 \\
\hline 78 & 6.4 & 6.6 & 158.9 & 99.0 & 6.9 & 6.5 & 620.2 & 98.8 \\
\hline 79 & 6.1 & 9.3 & 263.2 & 98.4 & 6.2 & 9.5 & 901.2 & 97.9 \\
\hline 80 & 14.7 & 19.3 & 323.8 & 98.3 & 13.4 & 19.5 & 1096.2 & 97.9 \\
\hline 81 & 2.1 & 4.0 & 439.8 & 97.9 & 2.1 & 4.0 & 1823.2 & 97.4 \\
\hline 82 & 3.7 & 3.0 & 458.7 & 97.8 & 3.6 & 3.0 & 1769.7 & 97.3 \\
\hline 83 & 8.1 & 11.3 & 58.9 & 80.5 & 8.1 & 10.4 & 55.9 & 166.5 \\
\hline 84 & 6.7 & 4.8 & 60.1 & 50.1 & 7.0 & 5.0 & 46.7 & 70.7 \\
\hline 85 & 16.8 & 12.5 & 66.0 & 49.1 & 17.3 & 13.1 & 51.7 & 40.8 \\
\hline 86 & 8.6 & 7.1 & 78.3 & 48.0 & 8.8 & 7.3 & 61.9 & 25.0 \\
\hline 87 & 6.7 & 6.8 & 50.0 & 101.5 & 6.5 & 7.4 & 70.9 & 197.5 \\
\hline 88 & 11.0 & 9.6 & 43.9 & 65.1 & 10.2 & 9.0 & 43.7 & 119.7 \\
\hline 89 & 7.9 & 8.1 & 54.0 & 48.4 & 7.9 & 8.3 & 40.5 & 59.6 \\
\hline 90 & 4.7 & 5.3 & 74.9 & 48.9 & 4.9 & 5.8 & 58.3 & 34.4 \\
\hline Overall: & 13.7 & 12.7 & 228.7 & 53.5 & 13.6 & 12.5 & 168.9 & 62.7 \\
\hline SD & 14.0 & 13.9 & 337.7 & 30.0 & 13.8 & 13.7 & 325.4 & 43.6 \\
\hline
\end{tabular}

a Details of the data is the same as Table S1. 
Table S6. The individual percentage deviations (IPDs) of solubilities of solutes in some of the solvents of this work predicted by equations (1) and (2) employing experimental and computed Abraham parameters

\begin{tabular}{|c|c|c|c|c|c|c|}
\hline \multirow[t]{2}{*}{ Solute } & \multirow[t]{2}{*}{ Solvent } & \multirow[t]{2}{*}{$T\left({ }^{\circ} \mathrm{C}\right)$} & \multicolumn{2}{|c|}{ Experimental parameters } & \multicolumn{2}{|c|}{ Computed parameters } \\
\hline & & & equation (1) & equation (2) & equation (1) & equation (2) \\
\hline Anthracene & 2-Propanol & 20 & 180.1 & 105.3 & 248.7 & 204.8 \\
\hline Anthracene & 2-Propanol & 25 & 43.1 & 4.9 & 78.1 & 55.7 \\
\hline Anthracene & 2-Propanol & 30 & 24.3 & 8.9 & 54.7 & 35.2 \\
\hline Anthracene & 2-Propanol & 35 & 7.9 & 32.5 & 14.6 & 0.2 \\
\hline Anthracene & 2-Propanol & 40 & 28.5 & 47.6 & 10.9 & 22.2 \\
\hline Anthracene & 2-Propanol & 45 & 27.8 & 47.1 & 10.1 & 21.4 \\
\hline Anthracene & 2-Propanol & 50 & 51.5 & 64.5 & 39.7 & 47.2 \\
\hline Anthracene & Heptane & 20 & 8.9 & 6.5 & 18.2 & 42.9 \\
\hline Anthracene & Heptane & 25 & 2.9 & 16.7 & 5.4 & 27.3 \\
\hline Anthracene & Heptane & 30 & 29.3 & 39.3 & 23.3 & 7.3 \\
\hline Anthracene & Heptane & 35 & 25.8 & 36.3 & 19.5 & 2.7 \\
\hline Anthracene & Heptane & 40 & 44.1 & 52.0 & 39.4 & 26.7 \\
\hline Anthracene & Heptane & 45 & 59.8 & 65.5 & 56.4 & 47.3 \\
\hline Anthracene & Heptane & 50 & 61.8 & 67.2 & 58.5 & 49.9 \\
\hline Anthracene & Toluene & 20 & 181.9 & 115.5 & 240.1 & 239.9 \\
\hline Anthracene & Toluene & 20 & 169.4 & 105.9 & 225.0 & 224.8 \\
\hline Anthracene & Toluene & 25 & 136.4 & 80.7 & 185.2 & 185.0 \\
\hline Anthracene & Toluene & 25 & 139.4 & 83.0 & 188.9 & 188.7 \\
\hline Anthracene & Toluene & 30 & 102.3 & 54.7 & 144.1 & 144.0 \\
\hline Anthracene & Toluene & 35 & 63.4 & 24.9 & 97.1 & 97.0 \\
\hline Anthracene & Toluene & 35 & 74.8 & 33.6 & 110.9 & 110.8 \\
\hline Anthracene & Toluene & 40 & 53.7 & 17.5 & 85.5 & 85.4 \\
\hline Anthracene & Toluene & 40 & 57.1 & 20.0 & 89.5 & 89.4 \\
\hline Anthracene & Toluene & 45 & 20.9 & 7.6 & 45.8 & 45.8 \\
\hline Anthracene & Toluene & 50 & 8.1 & 17.3 & 30.5 & 30.4 \\
\hline Anthracene & Toluene & 50 & 18.5 & 9.4 & 43.0 & 42.9 \\
\hline Benzoic acid & Carbon tetrachloride & 25 & 336.2 & 95.2 & 100.8 & 92.1 \\
\hline Benzoic acid & Carbon tetrachloride & 30 & 258.9 & 96.1 & 65.2 & 93.5 \\
\hline Benzoic acid & Cyclohexane & 25 & 690.6 & 93.4 & 176.6 & 90.9 \\
\hline Benzoic acid & Cyclohexane & 30 & 522.7 & 94.8 & 117.8 & 92.9 \\
\hline Benzoic acid & Heptane & 25 & 569.9 & 92.1 & 101.2 & 89.3 \\
\hline Benzoic acid & Heptane & 30 & 419.5 & 93.9 & 56.0 & 91.7 \\
\hline Benzoic acid & Hexane & 25 & 708.0 & 92.1 & 177.1 & 89.2 \\
\hline Benzoic acid & Hexane & 30 & 541.2 & 93.7 & 119.9 & 91.5 \\
\hline Benzophenone & Carbon tetrachloride & 25 & 49.2 & - & 64.4 & - \\
\hline Benzophenone & Decane & 25 & 28.7 & - & 25.9 & - \\
\hline Benzophenone & Dodecane & 25 & 182.0 & - & 64.7 & - \\
\hline Benzophenone & Heptane & 25 & 7.6 & - & 51.1 & - \\
\hline Benzophenone & Hexane & 25 & 87.7 & - & 8.3 & - \\
\hline Benzophenone & Nonane & 25 & 15.4 & - & 33.2 & - \\
\hline Benzophenone & Octane & 25 & 15.7 & - & 32.3 & - \\
\hline Carbazole & 2,2,4-Trimethylpentane & 25 & 761.8 & - & 158.0 & - \\
\hline Carbazole & Cyclohexane & 25 & 1967.8 & - & 661.6 & - \\
\hline Carbazole & Dibutyl ether & 25 & 391.4 & - & 57.4 & - \\
\hline Carbazole & Heptane & 25 & 333.7 & - & 193.8 & - \\
\hline Carbazole & Hexadecane & 25 & 1017.3 & - & 280.2 & - \\
\hline Carbazole & Hexane & 25 & 835.7 & - & 282.4 & - \\
\hline Carbazole & Methyl cyclohexane & 25 & 557.4 & - & 470.5 & - \\
\hline Carbazole & Heptane & 25 & 333.7 & - & 193.8 & - \\
\hline Carbazole & Hexane & 25 & 835.7 & - & 282.4 & - \\
\hline Carbazole & Octane & 25 & 1692.0 & - & 445.9 & - \\
\hline
\end{tabular}


Table S6. continuation

\begin{tabular}{|c|c|c|c|c|c|c|}
\hline \multirow[t]{2}{*}{ Solute } & \multirow[t]{2}{*}{ Solvent } & \multirow[t]{2}{*}{$T\left({ }^{\circ} \mathrm{C}\right)$} & \multicolumn{2}{|c|}{ Experimental parameters } & \multicolumn{2}{|c|}{ Computed parameters } \\
\hline & & & equation (1) & equation (2) & equation (1) & equation (2) \\
\hline Naphthalene & Benzene & 25 & 16.5 & 8.7 & 9.4 & 43.0 \\
\hline Naphthalene & Carbon tetrachloride & 25 & 33.6 & 29.8 & 37.1 & 8.7 \\
\hline Naphthalene & Cyclohexane & 25 & 28.7 & 46.1 & 39.0 & 21.6 \\
\hline Naphthalene & Hexadecane & 25 & 34.7 & 20.5 & 42.4 & 9.3 \\
\hline Naphthalene & Hexane & 25 & 46.6 & 37.3 & 54.1 & 8.7 \\
\hline Naphthalene & Toluene & 25 & 6.6 & 0.4 & 0.9 & 51.1 \\
\hline p-Benzoquinone & 2,2,4-Trimethylpentane & 25 & 54.8 & - & 44.4 & - \\
\hline p-Benzoquinone & Carbon tetrachloride & 25 & 68.0 & - & 8.8 & - \\
\hline p-Benzoquinone & Cyclohexane & 25 & 37.6 & - & 126.9 & - \\
\hline p-Benzoquinone & Dodecane & 25 & 47.5 & - & 83.3 & - \\
\hline p-Benzoquinone & Heptane & 25 & 16.7 & - & 215.2 & - \\
\hline p-Benzoquinone & Octane & 25 & 45.7 & - & 89.6 & - \\
\hline Phenanthrene & 2,2,4-Trimethylpentane & 20 & 46.7 & 41.8 & 17.6 & 72.5 \\
\hline Phenanthrene & 2,2,4-Trimethylpentane & 30 & 71.9 & 25.2 & 56.5 & 9.0 \\
\hline Phenanthrene & 2,2,4-Trimethylpentane & 40 & 88.4 & 69.2 & 82.1 & 62.5 \\
\hline Phenanthrene & 2,2,4-Trimethylpentane & 50 & 92.7 & 80.4 & 88.6 & 76.2 \\
\hline Phenanthrene & Heptane & 20 & 20.5 & 173.4 & 64.2 & 228.3 \\
\hline Phenanthrene & Heptane & 30 & 24.9 & 70.5 & 2.4 & 104.7 \\
\hline Phenanthrene & Heptane & 40 & 48.5 & 17.0 & 29.8 & 40.4 \\
\hline Phenanthrene & Heptane & 50 & 64.3 & 18.9 & 51.3 & 2.6 \\
\hline Phenanthrene & Toluene & 20 & 59.1 & 29.2 & 39.7 & 14.2 \\
\hline Phenanthrene & Toluene & 30 & 62.1 & 34.5 & 44.2 & 20.7 \\
\hline Phenanthrene & Toluene & 40 & 67.3 & 43.4 & 51.7 & 31.4 \\
\hline Phenanthrene & Toluene & 50 & 68.7 & 45.9 & 53.9 & 34.5 \\
\hline Phenyl acetic acid & 2,2,4-Trimethylpentane & 25 & 561.6 & 97.1 & 2363.6 & 96.5 \\
\hline Phenyl acetic acid & Carbon tetrachloride & 25 & 76.9 & 99.3 & 283.1 & 99.0 \\
\hline Phenyl acetic acid & Cyclohexane & 25 & 339.2 & 98.6 & 1405.1 & 98.2 \\
\hline Phenyl acetic acid & Heptane & 25 & 574.0 & 96.9 & 2107.4 & 96.2 \\
\hline Phenyl acetic acid & Octane & 25 & 701.5 & 97.2 & 2677.3 & 96.6 \\
\hline Pyrene & 2,2,4-Trimethylpentane & 20 & 80.2 & 37.8 & 51.7 & 29.3 \\
\hline Pyrene & 2,2,4-Trimethylpentane & 30 & 84.5 & 51.4 & 62.3 & 0.9 \\
\hline Pyrene & 2,2,4-Trimethylpentane & 40 & 86.1 & 56.4 & 66.2 & 9.4 \\
\hline Pyrene & 2,2,4-Trimethylpentane & 50 & 90.9 & 71.5 & 77.9 & 40.7 \\
\hline Pyrene & Heptane & 20 & 67.2 & 8.8 & 19.2 & 82.6 \\
\hline Pyrene & Heptane & 30 & 75.7 & 32.5 & 40.2 & 35.2 \\
\hline Pyrene & Heptane & 40 & 85.8 & 60.6 & 65.1 & 21.1 \\
\hline Pyrene & Heptane & 50 & 92.5 & 79.0 & 81.4 & 57.9 \\
\hline Pyrene & Toluene & 20 & 105.4 & 284.4 & 188.8 & 394.2 \\
\hline Pyrene & Toluene & 30 & 30.2 & 143.6 & 83.0 & 213.2 \\
\hline Pyrene & Toluene & 40 & 6.4 & 99.2 & 49.6 & 156.1 \\
\hline \multirow[t]{3}{*}{ Pyrene } & Toluene & 50 & 43.8 & 5.2 & 21.0 & 35.2 \\
\hline & & All & $207.2^{\mathrm{a}}$ & $59.1^{\mathrm{b}}$ & $188.0^{\mathrm{a}}$ & $73.6^{\mathrm{b}}$ \\
\hline & & 25 & $343.6^{\mathrm{c}}$ & $62.6^{\mathrm{d}}$ & $331.1^{\mathrm{c}}$ & $76.2^{\mathrm{d}}$ \\
\hline
\end{tabular}

${ }^{\mathrm{a}}$ The difference was not statistically significant (paired t-test, $\mathrm{p}>0.05$ ); ${ }^{\mathrm{b}}$ The difference was statistically significant (paired t-test, $\mathrm{p}<0.008$ ); ${ }^{\mathrm{c}}$ The difference was not statistically significant (paired t-test, $\mathrm{p}>0.05$ ); ${ }^{\mathrm{d}}$ The difference was not statistically significant (paired t-test, $\mathrm{p}>0.05$ ). 